ALEKSANDAR GRUBOR, Ph.D. ${ }^{1}$

E-mail: agrubor@ef.uns.ac.rs

JELENA KONČAR, Ph.D. ${ }^{1}$

E-mail: koncarj@ef.uns.ac.rs

RADENKO M. MARIĆ, Ph.D. ${ }^{1}$

E-mail: radenko.maric@ef.uns.ac.rs

GORAN VUKMIROVIĆ, Ph.D. ${ }^{1}$

(Corresponding author)

E-mail:vgoran@ef.uns.ac.rs

NIKOLA MILIĆEVIĆ, Ph.D. ${ }^{1}$

E-mail: milicevic.nikola@ef.uns.ac.rs

${ }^{1}$ University of Novi Sad

Faculty of Economics in Subotica

Segedinski put 9-11, 24000 Subotica, Serbia
Transport Logistics Original Scientific Paper Submitted: 25 Oct. 2019 Accepted: 11 May 2020

\title{
THE USE OF INTELLIGENT PACKAGING IN SUPPLY CHAIN OF FOOD PRODUCTS
}

\begin{abstract}
The research aims to identify the limitations and expectations of producers, transport companies, distributors and retailers in introducing intelligent packaging into supply chains of food products on the market of the Western Balkans. The limitations and benefits from the use of intelligent packaging have been identified in transportation, storage, operations of physical handling and display of food products at the place of their final purchase. The results have shown that there are significant differences in terms of limitations affecting the implementation of intelligent packaging into business operations of supply chains, bearing in mind the business type, number of employees, available capital and integrated standards into business operations. In contrast to this, the results point that there are no significant differences in terms of benefits that the analysed entities expect from introducing intelligent packaging into their systems. A set of measures and incentives have been defined for the competent institutions and food supply chain management to take, in order to minimize the restrictions and advance the implementation of intelligent packaging. The proposals and suggestions for further research are stated in the paper.
\end{abstract}

\section{KEY WORDS}

supply chains; intelligent packaging; retailing; physical distribution; food products; RFID; transport units;

\section{INTRODUCTION}

In academic circles there is an increasing presence of papers emphasizing the significance of intelligent packaging in transport, physical distribution and retail systems [1-3]. The use of smart solutions and contemporary technology in packaging has facilitated monitoring and has contributed to a more efficient supply chain. Together with timely information exchange, the use of packaging with RFID (Radio Frequency Identification) cards, GPS (Global Positioning System) tags, TTI (Time Temperature Indicator) and other chemical and biosensors enable a more precise planning of operations and better visibility of critical elements within the supply chain. This enables a solution closer to optimal inventory management, reduction in time of transport and delivery of products, and improvement in the efficiency of the entire chain [4]. In addition to providing modern technological solutions, intelligent packaging also includes the use of new materials for the production of the packaging itself. These can be new types of materials with different characteristics of permeability for different gases such as oxygen, carbon dioxide, nitrogen and steam, as well as materials resistant to high or low temperatures and other atmospheric conditions appearing during different transport and storing conditions [1].

Regarding the use of intelligent packaging, in the past years, we have seen the emergence of food packaging which offers maximum protection and preservation of use - value in the physical distribution process [2]. This is especially significant for supply chains of perishable goods, as only timely information exchange between participants enables 7P principle of delivery [5]. Thus, producers, transporters, wholesalers and retailers know the exact location of the products, delivery times, inventories, best-by dates, freshness and composition of matter. 
Numerous studies point to the inevitability of introducing intelligent packaging, primarily as a consequence of the growing process of market globalisation resulting in increasingly long supply chains of food products [6]. In addition to advantages in the communication and connectedness within the supply chains, studies $[7,8]$ confirm that intelligent packaging contributes to a reduction of total costs, with a simultaneous growth in productivity and business results of all participants. On the other hand, such optimization of supply chain management may help in reducing food waste, more efficient product return and the preservation of the environment [8]. The demands of the final consumer are also ineluctable. A study by Aday and Yener from 2015 shows that $75 \%$ of consumers buying food products packed into intelligent packaging does it due to visual ability to observe the history and freshness of packed food along the entire supply chain [9].

In the region of the Western Balkans, only a small number of academic research deals with the abovementioned problems. Studies to date have focused mainly on types and methods of intelligent packaging [10], the importance of intelligent packaging for the environment along the entire supply chain [11], the Western Balkans consumers' preference for the delivery of fresh food products [12], the importance of RFID technology in the processes of physical distributions [13], etc. The originality and scientific significance of the research lies in the fact that it defines analytically and systematically the limitations and expectations of all participants in the supply chain from the implementation of intelligent packaging in the supply processes of food products in the Western Balkans market. In contrast to the existing research conducted in the Western Balkans market [10-13], which indicated the importance of certain indicators in the application of intelligent food packaging (type of packaging, RFID technology, preservation of product freshness), the contribution of this paper is in the systematization, a comprehensive analysis and definition of the significance of all the limitations and expected benefits of implementing the intelligent packaging in the food supply chain. To understand the importance of introducing intelligent packaging and its impact on more efficient functioning of the food supply chain in the Western Balkans, the paper clearly defines and describes the importance of each restriction and benefit to producers, transport companies, distributors and retailers in the processes of transport, storage and physical-manipulative operations with food products. The contribution of the research is in proposing a set of measures and incentives to minimize the limitations and advance the benefits defined by empirical research.

The need for research stems from the fact that even though this technology keeps growing and showing that it can be completely commercially sustainable, in practical terms the integration of intelligent packaging into supply chains in the Western Balkans region is at the very beginning of use. Studies show that a very small number of producers, transporters and retailers in the Western Balkans market opt for the use of such a business concept because they face different obstacles and barriers that dominate, above all, the SMEs sector [10-14]. As the most frequent limitations for full incorporation of intelligent packaging on the Western Balkans market, the supply chain participants list high initial costs, price, indistinction of intelligent packaging on the market, lack of modern technologies, inadequate employee training, the unwillingness of all chain members to accept new technical and technological solutions, satisfaction with the existing packaging and packing systems, etc.

Having in mind the above-listed aspects, the subject of this paper is the analysis of the possibilities for using intelligent packaging in food supply chains, with an emphasis on perishable goods. The paper aims to identify the limitations and expectations available to all chain supply participants: producers, transporters, retailers and wholesalers in the region of the Western Balkans. Based on the results obtained, a set of measures will be proposed as an incentive to introduce intelligent packaging to the supply chain participants facing the biggest limitations. The empirical research was conducted on a sample of 114 companies (supply chain participants), to establish whether there are differences in advantages and limitations for introducing intelligent packaging into their business operations, depending on the business type, number of employees, available capital and integrated standards. The practical significance of the research is reflected in the fact that supply chain managers can identify the limitations preventing the use of intelligent packaging and take specific measures based on the obtained results to minimize them.

The paper is structured in five sections. Background and Literature Review points to the significance, role and place of intelligent packaging in 
food supply chains. Research hypotheses, research sample, applied methodology and statistical tools used for data processing are presented in the Section Methodology. Section Research Results presents the obtained data, descriptive statistic and testing results of proposed hypotheses. The discussion points to the limitations in the use of intelligent packaging and proposes specific measures and activities for their elimination. The Conclusion sums up the most important results of the study and gives suggestions for further research.

\section{BACKGROUND AND LITERATURE REVIEW}

Challenges faced by logistics in the food retail sector are numerous and centred on finding the balance between the demand for availability of high-quality, healthy and fresh food products on the one hand, and the lowest possible logistical costs on the other $[13,15]$. Solutions are sought in different areas and large-scale research, and one of the most current areas is the use of intelligent packaging. Intelligent packaging is a growing technology which uses the communicative function of packaging to facilitate the decision-making process of supply chain participants regarding the quality of the packed products, security, safety and speed of transport, storing conditions and exchange of information about products with final consumers [16]. Intelligent packaging represents an important evolutionary step, predominantly in the food retail sector, as it enables timely information exchange along the whole supply chain in compliance with product safety standards and provides final consumers with a better insight into their specific characteristics [17]. In other words, intelligent packaging is capable of discovering, capturing and following information on the quality and/or condition of products throughout the entire process of physical distribution. Advanced versions of intelligent packaging provide information not only on the product itself (origin, nutritional composition, etc.) but also information on the history of the product (storing conditions, temperature, humidity, moisture, micro-organisms, etc.). As such, it enables reconstructing the entire supply chain, from the production of the product (composition, raw materials and other materials), through manners and conditions of packing, transporting and storing, down to the final use [18].
To ensure the arrival of food products to their destination at the right time, right place and in the right condition without jeopardising quality, it is necessary to provide adequate transport and storage conditions, thereby reducing contamination risk and protecting food from various dangers. This resulted in the need to devise a system of exchange of automated information throughout the supply chain through bar codes, RFID, TTI, Integrity indicators, freshness indicators (ethylene sensors), gas $\left(\mathrm{O}_{2}\right.$ and $\mathrm{CO}_{2}$ ) concentration measurement indicators, biosensors, chemical sensors, etc. [18]. Owing to these characteristics, intelligent packaging has found a wide range of use in food production, transport and retail, with the emphasis on perishable goods such as fresh and processed meat, fish, fruit, vegetables, milk, etc. Concerning this, research shows that market share of packaging provided with TTI in the total produced packaging is $2 \%$, share of self-venting packaging is $6 \%$, share of packaging with bio-sensors for oxygen purification, detecting and removing humidity and eliminating $\mathrm{CO}_{2}$ is $7 \%$, the share of RFID technology is about $16 \%$, etc. [18, 19].

It is also important to point to specific reasons that have an impact on the increasing integration of intelligent packaging into supply chains. Authors $[20,21]$ list 15 critical supply chain areas appearing during the transport of food from production place to the place of final consumption. These are refrigeration and temperature control, transport unit management (prevention, sanitary protection, etc.), packing, loading and unloading, safety, control, container design, preventive maintenance, employees' hygiene, handling rejected weight, keeping, policies and traceability. The use of modern technologies (RFID, GPS tags, etc.) enables networking between food producers, transport companies and retailers [22, 23]. All information is stored into a central information system, which processes received data and activates warnings (e.g. on computers, smartphones or tablets), in cases when there are problems with temperature, humidity, product safety, packaging opening and repacking [20]. It is especially significant to point to the problems of repacking since intelligent packaging is often used for preventing forgeries in the chain itself. This reduces costs occurring as a consequence of large quantities of forgeries, i.e. fake products that the employees could replace for real ones during their movement through the supply chain [24]. It is also an inevitable fact that new intelligent packaging 
technologies are developing towards interaction with the end-user through the use of mobile applications and tablets (e.g. augmented reality) enabling intelligent packaging to communicate with the end-user. This way, greater marketing opportunities and increase in consumer curiosity justify the high costs of introducing smart elements [25].

Although the advantages stemming from the use of intelligent packaging are widely researched and documented, there is still an unexplored gap between the benefits and limitations that these technologies provide to supply chain participants. Danielli et al. [19] give a presentation of limitations ranked (scale 1-13) by producers, transport companies, retailers and technology providers. The supply chain participants state their satisfaction with conventional solutions as the greatest limitation (ank 1), the second place is taken up by the higher cost of packaging and products themselves, whereas high initial implementation costs come third. As the next limitation, the participants state that there is no clear demand for the use of intelligent packaging and precisely defined benefits for entities integrating it into their systems. Another problem is the long period of system installation, waiting for approvals and certificates of relevant institutions, etc. The authors single out SMEs as a group of companies most vulnerable to limitations, given that they often face a lack of funding and illiquidity, a lack of skilled labour, problems with standards, etc. Ghani et al. [18] include high final costs of intelligent packaging and insufficient efficiency of intelligent materials into two most important aspects limiting the exploitation of intelligent packaging systems. When it comes to costs of intelligent packaging system, they account for about $50 \%$ of the total costs of the final package today. However, for most food products, the price of the packaging must not exceed $10 \%$ of the total cost of the products placed on the shelves [25]. At the same time, technological advancement in the form of improved efficiency and performance of intelligent materials is required. The main criticism stems from a discrepancy between the results obtained by tests (in laboratories) and real data within the chain [18].

Some studies $[16-18,20]$ have indicated the great importance of various measures and incentives, which, depending on the market's development, modern technology use and employees' skills, minimize the given limitations significantly. From a financial aspect, credit lines with favourable interest rates which competent institutions (national and international funds, chambers of commerce, etc.) approve to the supply chain participants in the form of relief, are granted to producers, transport companies and distributors of food products for implementing intelligent systems. Important instruments of liquidity are tax relief and VAT exemptions and similar, which competent local and international institutions approve as financial incentives for the application of modern technology. National funds, employment services, development agencies and competent ministries also introduce special incentives for new hires for those supply chain participants who integrate intelligent packaging systems into their business processes. The reliefs given are related to prescribing lower tax rates for employees, subsidies for new employment, etc. It is up to the supply chain management itself to organize continuous training programs for employees, efficient transfer of knowledge, complete certification and standardization of equipment and processes, the establishment of regional clusters, etc.

Due to high regional, economic and demographic differences in the region of the Western Balkans, the use of intelligent packaging is in the first phase of introduction. A small number of producers, transporters and retailers opt for this form of technology for various reasons, while the SMEs sector uses it least [24]. Since this is a market (Croatia, Serbia, Bosnia and Herzegovina, Montenegro, Albania, and Macedonia) of over 20 million inhabitants, it is necessary to research the expectations and limitations appearing in the supply chain participants about the use of intelligent packaging and packing systems. The key research question should ask if there is a difference in limitations and expectations or if the size of a company, the business type, the number of employees, available capital and the standards integrated into business operations affect the use of intelligent technology of packaging food products.

\section{METHODOLOGY}

The research objective is to identify limitations and expectations that food supply chain participants in the Western Balkans region have from the use of intelligent packaging. In this context, it is necessary to establish whether there are differences in terms of limitations and expectations when introducing intelligent packaging depending on the business type, the number of employees, available capital and standards integrated into the business operation. 
The research objective is to define support to the companies in the form of measures with the highest impact on introducing intelligent packaging. Three hypotheses were defined based on the given objective.

H1-Limitations for the use of intelligent packaging differ significantly depending on the company's type and business characteristics as well as on resources of food products supply chain participants.

The established hypothesis is the result of previous research showing that the limitations to the introduction of intelligent packaging such as satisfaction with traditional packaging, high costs of introduction, high retail costs, long period of system installation, waiting for approvals and certificates of relevant institutions, etc., vary among different participants in the supply chain $[18,19]$. In this context, the participants are classified by the business type, the number of employees, capital and availability of standards in business operations.

H2 - Expectations for the use of intelligent packaging differ significantly depending on the company's type and business characteristics as well as on the resources of food products supply chain participants.

The expectations from the introduction of intelligent packaging systems are multiple, ranging from export growth, lower inventory costs, delivery timeliness and a more efficient supply chain, to increased profitability and extended product durability $[16,17,18,20]$. The expected benefits of introducing an intelligent packaging system are based on the company's motivation for generating additional revenue, while potential differences in expectations may have a foothold in the company's different position and role in the supply chain.

H3 - Credit lines, subsidies for new employees, tax relief and knowledge transfer have high influence on introducing intelligent packaging in the food supply chain.

If the hypothesis confirms that differences in limitations depend on the above variables, a set of measures will be proposed as an incentive to minimize their impact. Studies highlight a strong correlation between credit lines, subsidies for new employees, tax relief and knowledge transfer and a readiness to embrace the concept of intelligent packaging [16-19, 21].
Variables. To test the proposed hypotheses, the research included several variables. Supply chain participants were chosen as an independent grouping variable. They were grouped by business type (producers, transporters, wholesaler and retailers), the number of employees, available capital and standards integrated into business operations. The independent variable of interval type includes statements regarding limitations, expectations and measures related to introducing intelligent packaging. The dependent variables are limitations, expectations and incentives received based on the respondents' answers to statements posed in the questionnaires.

Research sample. The research included 114 companies, from the Western Balkans, which participate in the food supply chain and differ by business type, number of employees, available capital and implemented standards. The choice of companies in the sample was targeted, i.e. uniform according to various criteria. The producers accounted for the majority of the sample (47.4\%), as they represent the beginning of the chain in producing and packaging food products, and allocating most funds for the integration of intelligent packaging systems into supply chains. Other participants in the sample are equally represented as follows: transport companies $(18.4 \%)$, wholesalers $(14 \%)$ and retailers $(20.2 \%)$. According to the number of employees, research participants have been distributed equally. The number of small enterprises (up to 50 employees) was the highest $(27.2 \%)$, then medium-sized (25.4\%) and micro (24.6\%), while large enterprises (over 250 employees) were the fewest (22.8\%). The difference among companies in terms of standards was researched as well. The largest number in the sample, that is, $45.9 \%$ of them have ISO9000 standard, then ISO $9000+$ HACCP (29.8\%). A total of $9.6 \%$ of the research sample, has standards including ISO 9000 + HACCP + BRC standard. A certain number of respondents stated that they have no standards (14.7\%). Data on other particularities of the sample are given in Table 1. They show variability according to the characteristics of the companies that participated in the research.

Procedure and statistical analysis. The research was conducted in the period from July to September 2019. The respondents were middle level and top managers in renowned companies participating in the production and physical distribution of food in the Western Balkans area such as Carnex, 
Grubor A, Končar J, Marić R, Vukmirović G, Milićević N. The Use of Intelligent Packaging in Supply Chain of Food Products

Table 1 - Research sample

\begin{tabular}{||l|c|c|l|c|c||}
\hline \multicolumn{1}{|c|}{ Business area } & Number & Structure [\%] & \multicolumn{1}{c|}{ Number of employees } & Number & Structure [\%] \\
\hline \hline Production? & 54 & 47.4 & up to 10 & 28 & 24.6 \\
\hline Transport & 21 & 18.4 & up to 50 & 31 & 27.2 \\
\hline Wholesale & 16 & 14.0 & up to 250 & 29 & 25.4 \\
\hline Retail & 23 & 20.2 & over 250 & 26 & 22.8 \\
\hline Total & 114 & 100.0 & Total & Number & Structure [\%] \\
\hline \hline \multicolumn{1}{|c|}{ Available capital } & Number & Structure [\%] & & 52 & 45.9 \\
\hline \hline up to $100,000 €$ & 28 & 24.6 & SSO 9000 & 34 & 29.8 \\
\hline up to $500,000 €$ & 46 & 40.4 & ISO9000 + HACCP & 11 & 9.6 \\
\hline up to $1,000,000 €$ & 21 & 18.4 & ISO9000 + HACCP + BRC & 17 & 14.7 \\
\hline over $1,000,000 €$ & 19 & 16.7 & no standards & 114 & 100.0 \\
\hline Total & 114 & 100.0 & Total & & 24 \\
\hline
\end{tabular}

Matijević, Delta Transport Logistics, Nelt, FAS logistika, M transporti, Orbico, Mercator, Univerexport, Voli, PIK Vrbovec, Imlek, etc. The primary aim of the research is to test the key factors which influence the implementation of intelligent packaging in the food supply chain in the region of Western Balkans. The survey included business entities participating in the supply chains in multiple regional markets. Food manufacturers, transport companies and wholesalers sell their products and provide their services throughout the region in the markets of Serbia, Montenegro, Croatia, Northern Macedonia, Albania and Bosnia and Herzegovina. Retail chains such as Mercator, IDEA, Delhaize, Univerexport, Voli also operate in the markets of all Western Balkan countries. The presence of supply chain participants in different markets and the approaches used in managing intelligent packaging indicate that the problems and limitations for increasing the efficiency are relatively similar when looking at the national markets in the region. This approach to the research ensures the objectivity and representativeness of the data obtained through systematic observation of the food supply chain in the region of Western Balkans.

The respondents answered questions on limitations, expected benefits and measures as incentives for the introduction of intelligent packaging into their business systems. The questionnaire consisted of 31 questions for dependent variables of expectation (10 questions), limitations (11 questions), and measures (10 questions). The respondents' answers have been measured by the Likert scale (rank 1-5) and thus considered a continuous, interval variable. Since the goal has been to measure the correlation between variables of the interval type of measurement, Pearson's correlation coefficient is best suited for the application. In addition to this test, Spearman's correlation coefficient can be used to describe the correlation, but it is more robust and reserved for ordinal measurement scales. The correlation and grouping of variables can also be examined by Exploratory Factor Analysis (EFA), but in this paper, we wanted to treat the items as isolated ones.

The correlation, that is, differences based on sociodemographic characteristics and the respondents' answers to the statements were tested by ANOVA test since they are dependent variables of interval type and independent grouping variable with several categories. There was an option to test the correlation with the Spearman correlation, but this would imply that the growth on sociodemographic variables reflected the growth/decline on the dependent variables, and in some cases, it could be missed that only one group showed significantly different results. Scheffe's post hoc test was applied because it is a strict parameter for determining differences.

SPSS 20 statistical analysis program was used for data processing. Descriptive statistics was used for introducing the sample - frequencies for independent variables that are of the nominal and ordinal levels of measurement and descriptive indicators for dependent variables.

\section{RESEARCH RESULTS}

Research results and conducted testing were first presented for the group of questions regarding limitations to the use of intelligent packaging. Tendencies in attitudes can be defined by the use of descriptive statistics for examining respondents' answers to set statements (Table 2). Since the emphasis of the research is on the food supply chain and its participants, the classification according to the core 
Grubor A, Končar J, Marić R, Vukmirović G, Milićević N. The Use of Intelligent Packaging in Supply Chain of Food Products

Table 2 -Descriptive indicators of the variable of limitations to the use of intelligent packaging

\begin{tabular}{|c|c|c|c|c|c|}
\hline Indicators/statements & & Min. & Max. & Mean & SD \\
\hline \multirow{5}{*}{$\begin{array}{l}\text { Introduction of intelligent packaging will make a } \\
\text { negative impact on the level of satisfaction and of the } \\
\text { product/brand in the existing packaging. }\end{array}$} & Total & 3.00 & 5.00 & 3.6842 & .76789 \\
\hline & Production" & 2.00 & 5.00 & 3.7852 & .12982 \\
\hline & Transport & 1.00 & 3.00 & 3.5825 & 1.45623 \\
\hline & Wholesale & 3.00 & 5.00 & 3.3589 & .87423 \\
\hline & Retail & 3.00 & 5.00 & 4.0258 & .65298 \\
\hline \multirow{5}{*}{$\begin{array}{l}\text { Introduction of intelligent packaging will influence an } \\
\text { increase in the unit price of packaging and the product } \\
\text { itself, which will result in reduced demand. }\end{array}$} & Total & 3.00 & 5.00 & 4.2826 & .70198 \\
\hline & Production" & 3.00 & 5.00 & 4.4987 & .64328 \\
\hline & Transport & 1.00 & 4.00 & 3.9972 & .73867 \\
\hline & Wholesale & 1.00 & 4.00 & 3.7991 & .82901 \\
\hline & Retail & 3.00 & 5.00 & 4.7985 & .53098 \\
\hline \multirow{5}{*}{$\begin{array}{l}\text { Introduction of intelligent packaging will cause high } \\
\text { initial costs of implementation and reduce profitability } \\
\text { in the short run. }\end{array}$} & Total & 2.00 & 3.00 & 2.6053 & .49095 \\
\hline & Production" & 3.00 & 5.00 & 3.3895 & 1.21341 \\
\hline & Transport & 1.00 & 3.00 & 2.1982 & .25129 \\
\hline & Wholesale & 2.00 & 4.00 & 2.3987 & .98231 \\
\hline & Retail & 1.00 & 4.00 & 2.7098 & .36571 \\
\hline \multirow{5}{*}{$\begin{array}{l}\text { Supply chain participants do not have the same } \\
\text { criteria of the benefits of introducing intelligent } \\
\text { packaging. }\end{array}$} & Total & 2.00 & 4.00 & 3.0965 & .79789 \\
\hline & Production" & 3.00 & 5.00 & 3.3895 & .91842 \\
\hline & Transport & 2.00 & 4.00 & 3.0971 & .87341 \\
\hline & Wholesale & 1.00 & 4.00 & 3.1982 & .67301 \\
\hline & Retail & 3.00 & 5.00 & 2.7009 & .71082 \\
\hline \multirow{5}{*}{$\begin{array}{l}\text { The required period for installing intelligent } \\
\text { packaging systems does not suit the seasonal } \\
\text { character of production and distribution of products. }\end{array}$} & Total & 3.00 & 5.00 & 4.2719 & .65561 \\
\hline & Production" & 3.00 & 5.00 & 4.3895 & .54981 \\
\hline & Transport & 2.00 & 5.00 & 4.7149 & .29642 \\
\hline & Wholesale & 1.00 & 4.00 & 3.9974 & 1.93851 \\
\hline & Retail & 1.00 & 4.00 & 3.8914 & 1.42089 \\
\hline \multirow{5}{*}{$\begin{array}{l}\text { Process of standardization and obtaining various } \\
\text { approvals from relevant institutions has a limiting } \\
\text { impact on introducing intelligent packaging. }\end{array}$} & Total & 3.00 & 5.00 & 4.0965 & .71605 \\
\hline & Production" & 1.00 & 5.00 & 4.2895 & .71340 \\
\hline & Transport & 1.00 & 5.00 & 4.2998 & .63567 \\
\hline & Wholesale & 1.00 & 5.00 & 3.9974 & .82908 \\
\hline & Retail & 3.00 & 5.00 & 3.7526 & .89421 \\
\hline \multirow{5}{*}{$\begin{array}{l}\text { Consumers' education and their purchasing power are } \\
\text { significant factors of insufficient demand and market } \\
\text { potential for intelligent packaging. }\end{array}$} & Total & 3.00 & 4.00 & 3.5702 & .49724 \\
\hline & Production" & 3.00 & 5.00 & 4.0895 & .84657 \\
\hline & Transport & 1.00 & 4.00 & 3.1258 & 1.87341 \\
\hline & Wholesale & 1.00 & 4.00 & 2.6452 & 1.07684 \\
\hline & Retail & 3.00 & 5.00 & 4.4526 & .47230 \\
\hline \multirow{5}{*}{$\begin{array}{l}\text { Inadequate structure and training levels of staff } \\
\text { employed in product handling and manipulation } \\
\text { represent a significant limitation to the use of } \\
\text { intelligent packaging. }\end{array}$} & Total & 3.00 & 5.00 & 3.5877 & .59215 \\
\hline & Production" & 2.00 & 5.00 & 4.1778 & .62134 \\
\hline & Transport & 1.00 & 5.00 & 4.4526 & .74901 \\
\hline & Wholesale & 1.00 & 5.00 & 3.2458 & .65890 \\
\hline & Retail & 2.00 & 4.00 & 2.4452 & 1.11290 \\
\hline \multirow{5}{*}{$\begin{array}{l}\text { High price and lack of modern technology are } \\
\text { limiting factors for the use of intelligent packaging } \\
\text { in business processes. }\end{array}$} & Total & 4.00 & 5.00 & 4.4737 & .50151 \\
\hline & Production" & 3.00 & 5.00 & 4,6926 & .55671 \\
\hline & Transport & 1.00 & 4.00 & 4,2826 & .90092 \\
\hline & Wholesale & 1.00 & 4.00 & 3,9958 & .81930 \\
\hline & Retail & 3.00 & 5.00 & 4,7989 & .46992 \\
\hline \multirow{5}{*}{$\begin{array}{l}\text { Discrepancies between technical characteristics and } \\
\text { practical use of intelligent packaging }\end{array}$} & Total & 2.00 & 4.00 & 3.1842 & .78217 \\
\hline & Production" & 3.00 & 4.00 & 3.3073 & .57660 \\
\hline & Transport & 1.00 & 4.00 & 2.9863 & .72384 \\
\hline & Wholesale & 1.00 & 4.00 & 3.4128 & .64913 \\
\hline & Retail & 1.00 & 5.00 & 3.0223 & 1.63412 \\
\hline \multirow{5}{*}{$\begin{array}{l}\text { Questionable commercial benefit from introducing } \\
\text { intelligent packaging }\end{array}$} & Total & 3.00 & 5.00 & 4.2281 & .70441 \\
\hline & Production" & 3.00 & 5.00 & 4.3173 & 1.40021 \\
\hline & Transport & 2.00 & 5.00 & 4.2587 & .53891 \\
\hline & Wholesale & 2.00 & 5.00 & 3.9859 & .99723 \\
\hline & Retail & 1.00 & 5.00 & 4.3258 & 1.34831 \\
\hline
\end{tabular}


business (Production, Transport, Wholesale, Retail) will be an important element in the analysis of the obtained answers.

In the group of questions describing limitations, for the most part, the respondents agree on the statement that high price and lack of modern technology are limiting factors for the use of intelligent packaging in business processes $(M=4.47)$. The obtained statements about the high price of the introduction of intelligent technologies have been expected, since the market of the Western Balkans mostly includes transition countries (except for Croatia) that are characterized by the lack of funds, frequent insolvency of companies, debt collection problems, etc. The highest average score under this limitation is read by retailers $(M=4.79)$ and manufacturers $(\mathrm{M}=4.69)$, with the highest homogeneity of respondents' answers in case of these supply chain participants $(\mathrm{SD}=0.46 ; \mathrm{SD}=0.55)$. This is an expected response for retailers and manufacturers as they are in direct contact with the final consumers and business customers who respond to high prices by lowering the demand for particular products. The respondents agree, to a lesser extent, with the statement that intelligent packaging technology will cause high initial implementation costs and reduce the profitability in the short run $(\mathrm{M}=2.60)$. The greatest discrepancy for this statement was shown by transport companies $(\mathrm{M}=2.19)$, as they had already integrated smart elements for shipment tracking, such as GPS devices, RFID tags, navigation, etc. to a significant extent. The respondents in the transport companies also show the highest degree of agreement under this limitation $(\mathrm{SD}=0.25)$. The supply chain participants also state an increase in the unit price of packaging and the product itself as a significant limitation $(\mathrm{M}=4.28)$. This limitation is especially cited by retailers $(M=4.79)$ with high homogeneity of respondents' answers $(\mathrm{SD}=0.53)$, who emphasize that the problems are present in perishable goods, fresh and processed meat, milk and dairy products, fruit and vegetables, where packaging costs should account for only $10 \%$ of the total retail price of the product. The current share of intelligent packaging costs is about $40-50 \%$. In this respect, a serious limitation, especially in retailers $(\mathrm{M}=4.32)$ and producers $(\mathrm{M}=4.31)$ is manifested as questionable commercial benefit from introducing intelligent packaging $(\mathrm{M}=4.23)$. In terms of other responses of respondents with an above-average rating, the producers $(\mathrm{M}=4.38)$ and transport companies $(\mathrm{M}=4.71)$ mostly point to the long period which is required for the instalment of intelligent packaging systems, as not suitable for the seasonal character of the production and physical distribution of products such as fruit, vegetables, cereals, etc. $(\mathrm{M}=4.27)$. The respondents working in the manufacturing sector agree with the given restriction $(\mathrm{SD}=0.54)$, while employees in transport companies $(\mathrm{SD}=0.29)$ particularly agree with this statement.

Pearson's correlation analysis was applied to the correlation between ranked statements that examine the limitations. The results of the analysis show some correlations between these statements. The correlations are positively and negatively directed and in most cases are moderately and highly significant. The highest correlation is between statements describing limitations due to deviations in technical characteristics and practical application and limitations regarding high initial costs $(\mathrm{r}=0.583$, $\mathrm{p}<0.001)$. In addition to this, there is a high correlation between limitations coming from the standardization process and obtaining various approvals and limitations due to the lack of commercial benefit $(\mathrm{r}=0.526, \mathrm{p}<0.001)$. Unlike variations in statements about limitations, the respondents' answers are less variable in the case of expected benefits (Table 3).

As the most significant benefit, the respondents state the reduction in product return due to expired shelf life and the efficiency of reverse logistics systems $(M=4.21)$. The highest level of agreement regarding this statement is with manufacturers $(\mathrm{M}=4.59)$ and retailers $(\mathrm{M}=4.22)$. At the same time, the smallest discrepancies are offered by respondents in these groups $(\mathrm{SD}=0.54 ; \mathrm{SD}=.64)$ which indicates their unique viewpoint on the correlation of reverse logistics and the use of intelligent packaging. The respondents equally agree least with the statement that introducing intelligent packaging will influence a significant increase in business revenues $(\mathrm{M}=3.29)$.

The most significant benefits include the synchronization of food production, transport and distribution plans between supply chain participants $(\mathrm{M}=4.12)$ and the reduction of inventory costs $(\mathrm{M}=4.00)$. The highest agreement is among the respondents in the transport companies $(\mathrm{SD}=0.53)$, while the highest ratings are recorded by the manufacturers $(\mathrm{M}=4.49)$. Another important benefit is the reduction in inventory costs $(M=4.00)$, which is significant for the trade sector, that is, wholesale $(\mathrm{M}=4.30)$ and retail $(\mathrm{M}=4.00)$. Concerning these 
Grubor A, Končar J, Marić R, Vukmirović G, Milićević N. The Use of Intelligent Packaging in Supply Chain of Food Products

Table 3 -Descriptive indicators of the variable of expectations from the use of intelligent packaging

\begin{tabular}{|c|c|c|c|c|c|}
\hline Indicators/statements & & Min. & Max. & Mean & $\mathrm{SD}$ \\
\hline \multirow{5}{*}{$\begin{array}{l}\text { Introducing intelligent packaging will influence a } \\
\text { significant increase in our revenues. }\end{array}$} & Total & 2.00 & 5.00 & 3.2982 & .79745 \\
\hline & Production" & 1.00 & 4.00 & 3.3785 & 1.21839 \\
\hline & Transport & 1.00 & 5.00 & 3.2587 & .94371 \\
\hline & Wholesale & 2.00 & 5.00 & 3.1875 & .75099 \\
\hline & Retail & 2.00 & 5.00 & 3.2169 & .62371 \\
\hline \multirow{5}{*}{$\begin{array}{l}\text { I expect an increase in exports to other regional } \\
\text { markets of the Western Balkans, CEFTA and EU. }\end{array}$} & Total & 2.00 & 5.00 & 3.9211 & .84293 \\
\hline & Production" & 1.00 & 5.00 & 4.3387 & .75381 \\
\hline & Transport & 1.00 & 5.00 & 3.6421 & .82111 \\
\hline & Wholesale & 1.00 & 4.00 & 3.8181 & 1.24431 \\
\hline & Retail & 1.00 & 5.00 & 3.9023 & .77890 \\
\hline \multirow{5}{*}{$\begin{array}{l}\text { Use of intelligent packaging will facilitate } \\
\text { synchronization of production, transport and } \\
\text { distribution plans. }\end{array}$} & Total & 3.00 & 5.00 & 4.1228 & .59705 \\
\hline & Production" & 1.00 & 5.00 & 4.4985 & .63409 \\
\hline & Transport & 1.00 & 5.00 & 4.1007 & .53916 \\
\hline & Wholesale & 1.00 & 5.00 & 3.9014 & .99788 \\
\hline & Retail & 2.00 & 5.00 & 4.0179 & .87912 \\
\hline \multirow{5}{*}{$\begin{array}{l}\text { Introducing intelligent packaging will influence a } \\
\text { reduction in inventory costs. }\end{array}$} & Total & 1.00 & 5.00 & 4.0000 & 1.26910 \\
\hline & Production" & 1.00 & 4.00 & 3.7153 & 1.58914 \\
\hline & Transport & 1.00 & 5.00 & 4.0017 & .95823 \\
\hline & Wholesale & 3.00 & 5.00 & 4.3021 & .82311 \\
\hline & Retail & 2.00 & 5.00 & 4.0079 & 1.21510 \\
\hline \multirow{5}{*}{$\begin{array}{l}\text { Use of intelligent packaging will influence the } \\
\text { optimization of transport routes (fleet management) } \\
\text { and timeliness of deliveries }\end{array}$} & Total & 1.00 & 5.00 & 3.4737 & 1.14606 \\
\hline & Production" & 1.00 & 5.00 & 3.2153 & .91112 \\
\hline & Transport & 3.00 & 5.00 & 3.6317 & .74387 \\
\hline & Wholesale & 3.00 & 5.00 & 4.0121 & .63341 \\
\hline & Retail & 1.00 & 5.00 & 3.0139 & 1.34090 \\
\hline \multirow{5}{*}{$\begin{array}{l}\text { Use of intelligent packaging will influence speeding } \\
\text { up of physical and handling operations. }\end{array}$} & Total & 2.00 & 5.00 & 3.8246 & .89488 \\
\hline & Production" & 1.00 & 4.00 & 3.8997 & 1.41214 \\
\hline & Transport & 1.00 & 5.00 & 3.9717 & .72311 \\
\hline & Wholesale & 1.00 & 5.00 & 4.0121 & .55324 \\
\hline & Retail & 1.00 & 5.00 & 3.4239 & .87112 \\
\hline \multirow{5}{*}{$\begin{array}{l}\text { I expect a reduction in the return rate of our products } \\
\text { due to expiry date and/or defect. }\end{array}$} & Total & 3.00 & 5.00 & 4.2105 & .58708 \\
\hline & Production" & 2.00 & 5.00 & 4.5997 & .54632 \\
\hline & Transport & 3.00 & 5.00 & 3.9774 & 1.0019 \\
\hline & Wholesale & 2.00 & 5.00 & 4.0028 & .57782 \\
\hline & Retail & 3.00 & 5.00 & 4.2256 & .64901 \\
\hline \multirow{5}{*}{$\begin{array}{l}\text { Intelligent packaging will enable us to track our } \\
\text { products down to the moment of their consumption. }\end{array}$} & Total & 1.00 & 5.00 & 3.6754 & .96391 \\
\hline & Production" & 2.00 & 5.00 & 4.2571 & .43967 \\
\hline & Transport & 1.00 & 5.00 & 3.1314 & 2.1251 \\
\hline & Wholesale & 1.00 & 4.00 & 3.2287 & .97321 \\
\hline & Retail & 2.00 & 5.00 & 4.0871 & .32867 \\
\hline \multirow{5}{*}{$\begin{array}{l}\text { I expect our products to be better and more accessibly } \\
\text { displayed to consumers in an extended period. }\end{array}$} & Total & 1.00 & 5.00 & 3.5175 & 1.04104 \\
\hline & Production" & 1.00 & 5.00 & 4.0271 & 1.22216 \\
\hline & Transport & 1.00 & 4.00 & 3.0213 & .98654 \\
\hline & Wholesale & 1.00 & 4.00 & 2.9114 & .76512 \\
\hline & Retail & 1.00 & 5.00 & 4.1187 & .45881 \\
\hline \multirow{5}{*}{$\begin{array}{l}\text { I expect that final consumers will recognise the } \\
\text { quality of our products and that intelligent packaging } \\
\text { will increase their appeal. }\end{array}$} & Total & 2.00 & 5.00 & 3.4649 & .75469 \\
\hline & Production" & 2.00 & 5.00 & 3,9612 & .46781 \\
\hline & Transport & 1.00 & 5.00 & 2,8125 & 1.11283 \\
\hline & Wholesale & 1.00 & 5.00 & 2,9254 & 1.61960 \\
\hline & Retail & 3.00 & 5.00 & 4,1645 & .52130 \\
\hline
\end{tabular}


expectations, it is important to point out that the application of intelligent packaging enables the introduction of Quick Response - $Q R$ logistic concept [24]. Many large distributors in the food industry have adopted this integrated logistics concept. In QR, when products are bought, bar codes or RFID tags are scanned at the point of sale, and the information is sent directly to upstream chain members, distributors and producers. This way, every purchase, every reduction in inventories is recorded through intelligent elements, orders for new products are created automatically and thereby continuation of the production process is enabled, or vice versa, a necessary change in the distribution policy is made. It is important to point out that supply chain members expect the application of intelligent packaging to contribute to increased exports and more efficient placement of their products on other markets, primarily of EU member countries $(M=3.92)$. Manufacturers have the highest expectation regarding this statement $(\mathrm{M}=4.33)$, at the same time showing the highest degree of agreement $(\mathrm{SD}=0.75)$ with the fact that the use of modern technologies in packaging sector contributes to greater attractiveness of products and stimulation of exports. The remaining statements are equally ranked among the respondents.

The results of Pearson's correlation analysis in the case of expectations show weak and moderate correlations between ranked statements. The highest correlation is between statements that indicate product quality recognition and the ability to track the product until final consumption $(\mathrm{r}=-0.472$, $\mathrm{p}<0.01$ ), as well as between statements that suggest optimizing transportation routes and increasing revenue $(\mathrm{r}=0.377, \mathrm{p}<0.01)$.

One-way analysis of variance was used for testing the proposed hypotheses. The analysis was first used to examine whether there are statistically significant differences in limitations viewed by independent grouping variables of the business type, the number of employees, available capital and implemented standards. The applied analysis showed that there is a statistically significant difference between supply chain participants from different industries. When viewing individual items, it can be observed that the difference is found in more than half of the statements. F-test values and significance for statistically significant statements are given in Table 4.

Scheffe's post hoc test showed that the use of intelligent packaging will influence the increase of the unit price of both packaging and the product itself, which will result in reduced demand. Retailers and transport companies have the highest scores, while wholesalers have the lowest. The statement, that supply chain participants do not have the same criteria for the benefit from applying the intelligent packaging is the least agreed on by producers and the most by transport companies. Significant differences are also registered in statements relating to the process of standardization and commercial sustainability of intelligent packaging. The statement, that the process of standardization and obtaining various approvals from competent institutions has

Table 4 - Differences depending on business areas of supply chain participants

\begin{tabular}{|l|c|c||}
\hline \multicolumn{1}{|c|}{ Indicators/statements } & F & Significance \\
\hline \hline $\begin{array}{l}\text { Use of intelligent packaging will influence the increase in unit prices of } \\
\text { packaging and product itself, which will cause a reduction in demand. }\end{array}$ & 6.247 & $.001^{*}$ \\
\hline $\begin{array}{l}\text { Introducing intelligent packaging will cause high initial implementation costs } \\
\text { and reduce profitability in the short run. }\end{array}$ & 3.452 & $.015^{*}$ \\
\hline $\begin{array}{l}\text { The required period for installing intelligent packaging system does not suit } \\
\text { the seasonal character of production and distribution of products. }\end{array}$ & 2.872 & $.040^{*}$ \\
\hline $\begin{array}{l}\text { Process of standardization and obtaining various approvals from relevant } \\
\text { institutions has a limiting impact on introducing intelligent packaging. }\end{array}$ & 4.748 & $.004^{* *}$ \\
\hline $\begin{array}{l}\text { Consumers' education and their purchasing power are significant factors of } \\
\text { insufficient demand and market potential for intelligent packaging. }\end{array}$ & 14.415 & $.000^{* *}$ \\
\hline $\begin{array}{l}\text { Inadequate structure and training levels of staff employed in product handling } \\
\text { and manipulation represent a significant limitation to the use of intelligent } \\
\text { packaging. }\end{array}$ & 4.733 & $.004^{* *}$ \\
\hline Questionable commercial benefit from introducing intelligent packaging & 3.659 & $.015^{*}$ \\
\hline
\end{tabular}

*Significant at $5 \%$; **ignificant at $1 \%$ 
a limiting influence on introducing intelligent packaging is least agreed on by transporters, and most agreed by wholesalers. On the other hand, questionable commercial benefit from introducing intelligent packaging is the most present among respondents involved in production and retail, and the least among respondents involved in transport.

In terms of the number of employees, the supply chain participants are also divided into four groups. There is a statistically significant difference between these groups. The difference was obtained by utilizing a one-way analysis of variance. F-test amounts to $9.446, \mathrm{p}<0.001$. Table 5 shows the differences in terms of the number of employees. Limitations are seen most within SMEs, especially in micro-companies group up to 10 employees. They differ significantly with respondents who employ over 250 employees. The biggest limitation for the participants with a small number of employees is inadequate structure and training level of staff in product handling and manipulation $(\mathrm{F}=6.622$, $\mathrm{p}<0.001$ ), the long period for installing intelligent packaging systems $(\mathrm{F}=4.814, \mathrm{p}<0.001)$, an increase in the unit price of packaging and the product itself $(\mathrm{F}=11.371, \mathrm{p}<0.001)$, lack of modern technology $(\mathrm{F}=2.862, \mathrm{p}<0.05)$, questionable commercial benefit $(\mathrm{F}=3.334, \mathrm{p}<0.001)$ and the long period of standardization process $(\mathrm{F}=4.845, \mathrm{p}<0.05)$.

Table 5 - Average ratings of differences depending on the number of employees of supply chain participants

\begin{tabular}{||c|c|c||}
\hline Number of employees & 1 & 2 \\
\hline \hline over 250 & 3.6023 & \\
\hline up to 250 & & 3.6945 \\
\hline up to 50 & & 3.7727 \\
\hline up to 10 & & 3.9351 \\
\hline
\end{tabular}

There is a statistically significant difference between groups with available capital in terms of limitations by all statements $(\mathrm{F}(3,114)=4,966$, $\mathrm{p}<0.001)$. Scheffe's post hoc test established that there are differences between companies with over EUR 1,000,000 of available capital and other companies - SMEs (Table 6). These participants are satisfied with the existing packaging solutions $(\mathrm{F}=4.745$, $\mathrm{p}<0.001$ ), doubt consumers' education and their purchasing power $(\mathrm{F}=6.142, \mathrm{p}<0.001)$, and believe that not all supply chain participants have the same criteria for the benefit from introducing intelligent packaging into food packaging systems $(\mathrm{F}=6.791$, $\mathrm{p}<0.001$ ).
Table 6 - Average ratings of differences depending on the available capital of supply chain participants

\begin{tabular}{|c|c|c||}
\hline Available capital & 1 & 2 \\
\hline \hline over $€ 1,000,000$ & 3.5238 & \\
\hline over $€ 1,000,000$ & & 3.7312 \\
\hline up to $€ 500,000$ & & 3.7727 \\
\hline up to $€ 100,000$ & & 3.7943 \\
\hline
\end{tabular}

The supply chain participants also differ in the assessment of limitations in terms of implemented standards $(\mathrm{F}(3,110)=14,136, \mathrm{p}<0.001)$. Companies with all implemented standards have the lowest scores in limitations assessment. They believe that they have trained employees, approvals from competent institutions and all prescribed standards, which, at the same time, shorten the period required for installing the intelligent packaging systems. On the other hand, the participants with no standards implemented give the highest ratings to the statements describing limitations.

Table 7 - Average ratings of differences depending on the adopted standards of supply chain participants

\begin{tabular}{|c|c|c|c||}
\hline Adopted standards & 1 & 2 & 3 \\
\hline \hline $\begin{array}{c}\text { ISO9000+ HACCP }+ \\
\text { BRC standard }\end{array}$ & 3.4628 & & \\
\hline ISO9000 & & 3.6818 & \\
\hline ISO9000+HACCP & & 3.6925 & \\
\hline no standards & & & 4.0160 \\
\hline
\end{tabular}

Based on the applied analysis and the obtained results, it is observed that hypothesis $\mathrm{H} 1$ is accepted. The conclusion is that the limitations of food supply chain participants of the Western Balkans region in terms of the application of intelligent packaging vary and differ depending on the business type, the number of employees, available capital and implemented standards. In other words, different supply chain participants evaluate differently the obstacles and limitations in introducing intelligent food product packaging systems.

After the analysis of differences by attitudes to limitations, the authors examined whether there are differences in expectations among supply chain participants. A range of one-way variance analyses was applied. All one-way variance analyses showed that there is no statistically significant difference in expectations between companies according to their business activity, resources, capital and standards. There are no differences either on the total score or individual items. Based on the conducted testing, it 
Grubor A, Končar J, Marić R, Vukmirović G, Milićević N. The Use of Intelligent Packaging in Supply Chain of Food Products

Table 8 - Measures as incentives to introduce intelligent packaging into supply chains

\begin{tabular}{|l|c|c||}
\hline \multicolumn{1}{|c|}{ Measures } & Mean & Std. Deviation \\
\hline \hline Credit lines & 4.8043 & 1.02458 \\
\hline Subsidies for new employees & 4.5870 & 1.02363 \\
\hline Tax relief & 4.6304 & 1.18056 \\
\hline Knowledge transfer & 4.3478 & .99370 \\
\hline $\begin{array}{l}\text { Exemption from VAT on equipment for the production and introduction of intelligent } \\
\text { packaging }\end{array}$ & 4.0870 & 2.95767 \\
\hline Free of charge training for employees engaged in the field of intelligent packaging & 3.1957 & 1.84535 \\
\hline Assistance in preparation of permits and standards & 2.8261 & 1.27025 \\
\hline Establishment of a cluster with the support of the University & 3.8261 & 1.51003 \\
\hline Intelligent packaging system maintenance and repair services & 4.2391 & 1.50827 \\
\hline Facilities when purchasing intelligent packaging materials & 3.5435 & 1.91725 \\
\hline
\end{tabular}

has been found that hypothesis $\mathrm{H} 2$ is rejected. The conclusion is that all food supply chain participants of the Western Balkans region have identical expectations from the use of intelligent packaging regardless of the business type, the number of employees, available capital and standards implemented in the business operations.

Given that hypothesis $\mathrm{H}_{1}$ is confirmed and that differences are found in the limitations to the introduction of intelligent packaging into food supply chains, $\mathrm{H}_{3}$ is now being tested to determine what measures need to be taken to minimize these limitations in the Western Balkans market. The participants ranked the extent to which the measures offered, act as incentives for integrating intelligent packaging into their business systems. The results of the answers are shown in Table 8.

Based on the data obtained, it can be seen that the highest score is achieved by the credit lines measure $(\mathrm{M}=4.8, \mathrm{SD}=1.02)$, while the lowest score is achieved by assistance in the preparation of permits and standards $(\mathrm{M}=2.82, \mathrm{SD}=1.27)$. The respondents' answers differ most in their assessment of the measure exemption from VAT on equipment for the production and introduction of intelligent packaging $(\mathrm{M}=4.09, \mathrm{SD}=2.96)$. SMEs consider this measure as a very significant incentive, while large participants in the supply chain hardly value it at all and rank it as insignificant. Further testing shows that there is a statistically significant difference between the measures themselves $(\mathrm{F}(9,114)=98.01, \mathrm{p}<0.001)$. The comparison between the measures shows that the credit lines, subsidies for new employees, tax relief and knowledge transfer do not differ significantly from one another but differ significantly from other items. Such a result suggests that $\mathrm{H}_{3}$ is confirmed and that measures such as credit lines, subsidies for new employees, tax relief and knowledge transfer are recognized as actual incentives to remove limitations to the introduction of intelligent packaging into supply chains. It is important to point out that the results of the Scheffe's post hoc test show differences between the participants in the supply chain in terms of evaluating the above measures. A statistically significant difference was observed between SMEs (up to 250 employees, up to $€ 1.000 .000$ available capital) and large enterprises for all four of these measures. The result shows that SMEs, as participants in the food supply chain, identify measures such as credit lines, subsidies for new employees, tax relief and knowledge transfer as actual incentives that can help them remove barriers and minimize limitations to the introduction of intelligent packaging systems.

\section{DISCUSSION}

The conducted research confirmed the results of previous studies $[18,19]$ that barriers and limitations to introducing intelligent packaging are satisfaction with conventional packaging solutions, high final retail price, high final costs of intelligent packaging systems, high initial implementation costs, long period of introducing modern intelligent packaging technology, insufficient staff training, final consumers' lack of interest, insufficient efficiency and performance of intelligent materials. On the other hand, the expected benefits [16-19] of reduction in product return rate due to expired shelf life, more efficient synchronisation of production, transport and distribution plans, reductions in inventory costs, increase in exports and more efficient product placement on other markets etc. have been also confirmed. 
The originality of this research is reflected in the fact that the expected benefits from introducing intelligent packaging systems of food products are identical for all the supply chain participants. Producers, transporting companies, wholesalers and retailers, regardless of the number of employees, available capital and standards point identically to benefits brought on by the application of such a business concept. At the same time, however, differences between participants impose different kinds of limitations and barriers they face when implementing intelligent packaging.

The results obtained for the Western Balkans partly deviate from the results of related studies conducted in the EU countries. In terms of restrictions, until 2004, they had been particularly emphasized in supply chains across the EU, given that there was a legislative shortcoming for this type of packaging, which reduced its penetration in the sectors of production, transport, storage and food retail [29, 30]. By regulations of 2004 (1935/2004 / EC) and 2009 (450/2009 / EC), the EU defined a new framework to enable the correct use, safety and placing of intelligent packaging on the market [28]. In this way, the restrictions on its full integration into the EU food supply chain have been significantly reduced.

To summarize, according to the obtained results, in the Western Balkans region, the greatest limitations are faced by SMEs, especially micro-companies with up to 10 employees with available capital up to 100,000 EUR and without any implemented standards in their business operations. Their greatest problems are high price and initial costs of introducing intelligent packaging, lack of modern technologies, insufficient staff training and complicated procedures of obtaining approvals and certificates from competent institutions. Given that micro-enterprises significantly participate in the supply chain activities, especially of food products (e.g. small processors and small farms, small independent transporters, independent retailers, specialised stores, etc.) [26], competent ministries, bodies and associations must define a whole set of measures and policies to encourage these participants to introduce intelligent packaging systems. The research results have shown that these measures should include more favourable credit lines for the application of intelligent packaging elements, tax reliefs, subventions for new employees, free staff training, subsidies for gradual digitalization of business activities (e.g. introducing Internet of Things, RFID technology), co-financing in the introduction of smart technologies (e.g. Blockchain smart technology as a common digital platform where supply chain participants can store and share information across the chain and view all transactions simultaneously in real-time, without the possibility of changing data, hacking, or deleting [28]), etc.

Furthermore, there should be mutual vertical cooperation and integration in the supply chain itself, where companies sharing common interests regarding the introduction of intelligent packaging would cooperate on issues of finance, human resources and technology, and thus eliminate obstacles, provided that those vertical integrations are legally permitted. Also, competent Ministries of Environmental Protection or Ecology in the Western Balkans region should introduce legal solutions, by-laws and rule books on compulsory phase-in to intelligent packaging systems, as well as the adoption of compulsory international standards, such as ISO 17363:2013 Supply chain applications of RFID Freight containers (cargo shipment identification); ISO 17365:2013 Supply chain applications of RFID - Transport units (transport unit identification); ISO 17366:2013 Supply chain applications of RFID Product packaging (package and packaging identification); ISO 17367:2013 Supply chain applications of RFID - Product tagging (product tagging and identification) etc. In addition to that, competent institutions should work on creating a favourable business environment through developing modern infrastructural, logistics and distribution networks.

Finally, enormous differences among participants are also present regarding the dimension of the business type. The research results have shown that the greatest discrepancies are present in cases of pricing and standardization process. The final retail price represents the main barrier for producers and retailers, whereas the standardization process problems are mostly pointed out by wholesalers. Substantial differences are identified in consumers' purchasing power, which directly correlates to wholesale and retail, and does not represent a barrier in transport companies. Unclear performance of intelligent packaging is partially unclear to retailers, whereas for producers and transport companies another significant problem is the long period of introducing intelligent packaging which very often fails to beconsistent with the seasonal character of production and distribution of food products. Commercial sustainability of intelligent packaging 
on the market is the least worrying to transport companies, whereas it is emphasized by producers and retailers.

Intelligent packaging has a huge potential for all supply chain participants despite the emphasized limitations. The conducted research has shown that it contributes to improved security and safety of food products, preservation of their quality and use value in transport, distribution and storage. It also has other benefits which are significant to all types of companies and final consumers themselves. Intelligent packaging is a way of securing better traceability in the food supply chain.

\section{CONCLUSION}

The need for research on the implementation of intelligent packaging into food supply chains stems from the fact that it is a growing technological concept with increasing practical use. Regardless of whether one discusses global food placement or work with local suppliers, the supply chain participants must secure a high level of quality and safety for their final products at any moment. The higher the visibility in the supply chain and the more efficient communication between participants, there is more possibility of more efficient management in the chain itself. Focus on intelligent packaging, quick response logistics and smart technology will result in an efficient supply chain of high-quality final products and loyal customers. In this context, the conducted research on the sample of 114 participants in the food supply chain in the Western Balkans region identified precisely all the limitations to full exploitation of intelligent technologies on the one hand, and at the same time, pointed to the expected benefits from packing products into intelligent packaging on the other. In the context of results, some specific measures were proposed, which should equalize the possibilities of using intelligent packaging among all chain participants.

Shortcomings of the conducted research refer to the limiting research area, that is, to the Western Balkans region. The objective reason for choosing the given region is the fact that the authors are familiar with the economic trends in the regional market. Including a larger number of countries from the global market would require significant financial resources, production knowledge, distributive infrastructure and consumer habits in these countries.
Within the guidelines for future research, the analysis should be extended and a comparison should be made between the Western Balkans countries, as well as a comparison between EU and nonEU countries. The analysis itself should encompass more sub-categories within the offered statements on a larger research sample. Such research approach would complete the scientific and expert insight into the possibilities of using intelligent packaging in the food supply chains.

\section{ACKNOWLEDGEMENT}

The paper is the result of the research on the project "Possibility of use of intelligent packaging as a segment of green marketing logistics in the function of sustainable development in the AP Vojvodina market" which is part of the cycle of "Short-term Projects of Special Interest for Sustainable Development in AP Vojvodina in 2019“, financed by the Provincial Secretariat for Higher Education and Scientific Research of AP Vojvodina.

\section{Prof. dr. ALEKSANDAR GRUBOR ${ }^{1}$}

E-mail: agrubor@ef.uns.ac.rs

Prof. dr. JELENA KONČAR ${ }^{1}$

E-mail: koncarj@ef.uns.ac.rs

Prof. dr. RADENKO M. MARIĆ ${ }^{1}$

E-mail: radenko.maric@ef.uns.ac.rs

Doc. dr. GORAN VUKMIROVIĆ

(Koresponding autor)

E-mail: vgoran@ef.uns.ac.rs

Doc. dr. NIKOLA MILIĆEVIĆ ${ }^{1}$

E-mail: milicevic.nikola@ef.uns.ac.rs

${ }^{1}$ Univerzitet u Novom Sadu, Ekonomski fakultet u Subotici, Segedinski put 9-11, 24000 Subotica, Srbija

\section{PRIMENA INTELIGENTNE AMBALAŽE U LANCU SNABDEVANJA PREHRAMBENIH PROIZVODA}

\section{REZIME}

Cilj istraživanja je da se identifikuju ograničenja $i$ očekivanja proizvođača, transportnih preduzeća, distributera i maloprodajnih preduzeća od uvođenja inteligentne ambalaže u lance snabdevanja prehrambenih proizvoda na tržištu Zapadnog Balkana. Identifikovana su ograničenja i faktori koji pozitivno utiču na uvođenje i ubrzanu primenu inteligentne ambalaže $u$ transportu, skladištenju, fizičko-manipulativnim operacijama i izlaganju prehrambenih proizvoda. Rezultati su pokazali da postoje značajne razlike u pogledu ograničenja koja imaju uticaj na uvođenje inteligentne ambalaže u poslovne procese učesnika lanca snabdevanja, uvažavajući oblasti poslovanja, broj zaposlenih, raspoloživi kapital i usvojene standarde u poslovanju. Nasuprot tome, rezultati 
ukazuju da ne postoje značajne razlike kada je reč o koristi koju analizirani subjekti očekuju od uvođenja inteligentne ambalaže u svoje sisteme. Definisan je niz mera $i$ podsticaja koje nadležne institucije $i$ menadžment lanca snabdevanja prehrambenih proizvoda treba preduzeti kako bi se smanjila ograničenja $i$ unapredila primena inteligentne ambalaže. Predlozi i sugestije za buduća istraživanja navedeni su u radu.

\section{KLJUČNE RE ̌ I}

lanci snabdevanja; inteligentna ambalaža; maloprodaja; fizička distribucija; prehrambeni proizvodi; RFID; transportne jedinice;

\section{REFERENCES}

[1] Ait-Oubahou A, Hanani ZN, Jamilah B. Packaging. In: Yahia EM (ed.) Postharvest Technology of Perishable Horticultural Commodities. Sawston. UK: Woodhead Publishing; 2019. p. 375-399.

[2] Preda M, Popa M-I, Mihai MM, Şerbănescu AA, Holban AM. Natural fibers in beverages packaging. In: Grumezescu MA, Holban, AM (ed.) Trends in Beverage Packaging. Cambridge, USA: Academic Press; 2019. p. 409-424.

[3] Bledsoe G, Rasco B. Recent advances on intelligent and active packaging in food and beverage technology. Food Health and Technology Innovations. 2018;1(2): 72-74.

[4] Hasani M. Wearable Passive RFID Tags in Advanced Uses: Detection Methods for RFID-Enabled Sensor Tags and RFID-based Localization. $\mathrm{PhD}$ thesis. Tampare: Tampare University of Technology; 2018.

[5] Jacyna M. The urban logistic service model in the aspect of the domestic logistic system. In: Pratelli A, Brebbia AC. (ed.) Urban Transport XVII: Urban Transport and the Environment in the $21^{\text {st }}$ Century. WIT Press; 2011. p. 121-128.

[6] Siracusa V, Lotti N. Intelligent packaging to improve shelf life. In: Galanakis MC. (ed.) Food Quality and Shelf Life. Elsevier; 2019. p. 261-277.

[7] Heising JK, Dekker M, Bartels PV, Van Boekel MA. Monitoring the quality of perishable foods: Opportunities for intelligent packaging. Critical Reviews in Food Science and Nutrition. 2014;54(5): 645-654.

[8] Heising JK, Claassen GDH, Dekker M. Options for reducing food waste by quality-controlled logistics using intelligent packaging along the supply chain. Food Additives \& Contaminants: Part A. 2017;34(10): 1672-1680.

[9] Aday MS, Yener U. Assessing consumers' adoption of active and intelligent packaging. British Food Journal. 2015;117(1): 157-177.

[10] Jakupić M, Poljan M, Hajdek M. Pametna ambalaža. Polytechnic \& Design. 2019;7(2): 144-153.

[11] Lazić V, Novaković D. Ambalaža i životna sredina. Novi Sad: Univerzitet u Novom Sadu, Tehnološki fakultet; 2010.

[12] Giraud G, Amblard C, Thiel E, et al. A cross-cultural segmentation of western Balkan consumers: Focus on preferences toward traditional fresh cow cheese. Journal of the Science of Food and Agriculture. 2013;93(14): 3464-3472.

[13] Nikoličić S, Kilibarda M, Atanasković P, Duđak L, Ivanišević A. Impact of RFID technology on logistic process efficiency in retail supply chains. PrometTraffic \& Transportation. 2015;27(2): 137-146.

[14] Raković L, Sakal, M, Matković P, Vuković V, Pavlićević V. Empirical Study on Spreadsheet Quality: Case of Serbian SMEs. Strategic Management. 2019;24(2): 58-64.

[15] Tešić D. Measuring dimensions of service quality. Strategic Management. 2020;25(1): 29-34.

[16] Yam KL, Takhistov PT, Miltz J. 2005. Intelligent packaging: Concepts and uses. Journal of Food Science. 2005;70(1): 1-10.

[17] Bento LM, Silva MCPD, Chaves KDS, Stefani R. Development and evaluation of a smart packaging for the monitoring of ricotta cheese spoilage. MedCrave Online Journal (MOJ) of Food Processing \& Technology. 2015;1(1): 9-11.

[18] Ghaani M, Cozzolino CA, Castelli G, Farris S. An overview of the intelligent packaging technologies in the food sector. Trends in Food Science \& Technology. 2016;51: $1-11$.

[19] Dainelli D, Gontard N, Spyropoulos D, Zondervan-van den Beuken E, Tobback P. Active and intelligent food packaging: Legal aspects and safety concerns. Trends in Food Science \& Technology. 2008;19: 103-112.

[20] Maksimović M, Vujović V, Omanović-Miklićanin E. Use of internet of things in food packaging and transportation. International Journal of Sustainable Agricultural Management and Informatics. 2015;1(4): 333-350.

[21] Ryan JM. Guide to Food Safety and Quality During Transportation: Controls, Standards and Practices. Elsevier; 2014.

[22] Vojvodić K. Brick-and-Mortar Retailers: Becoming Smarter with Innovative Technologies. Strategic Management. 2019;24(2): 3-11.

[23] Vučenović S. Internet of Things as innovative technology in retailing. Anali Ekonomskog fakulteta u Subotici. 2018;54(39): 249-256.

[24] Li L. Technology designed to combat fakes in the global supply chain. Business Horizons. 2013;56(2): 167-177.

[25] Đurđević S, Novaković D, Zeljković Ž, Avramović D. Using Augmented Reality Technology for Controlling State of Smart Packaging Products. University of Novi Sad, Faculty of Technical Sciences, Preliminary report, 2016. p. 427-437.

[26] Končar J, Grubor A, Marić R, Vukmirović G, Đokić N. Possibilities to improve the image of food and organic products on the AP Vojvodina market by introducing a regional quality label. Food and Feed Research. 2019;46(1): 111-124.

[27] Krpan Lj, Furjan M, Maršanić R. Potencijal logistike povrata u maloprodaji. Technical Journal. 2014;8(2): 182191.

[28] Breese JL, Park SJ, Vaidyanathan G. Blockchain technology adoption in supply change management: Two theoretical perspectives. Issues in Information Systems. 2019;20(2): 140-150.

[29] Restuccia D, Spizzirri UG, Parisi OI, et al. New EU regulation aspects and global market of active and intelligent packaging for food industry applications. Food control. 2010;21(11): 1425-1435.

[30] Vanderroost M, Ragaert P, Devlieghere F, De Meulenaer B. Intelligent food packaging: The next generation. Trends in Food Science \& Rechnology. 2014;39(1): 4762. 